\title{
Beyond Genocide: a comparative analysis of the elimination of Australia's Indigenous and Torres Strait Islander people
}

\author{
Thomas Crotty
}

\begin{abstract}
This paper explores the applicability of the term genocide to Australian colonisation, and considers whether the scholar Patrick Wolfe's concept of settler colonialism's inherent "logic of elimination" provides a more useful framework for considering Australian history.
\end{abstract}

Keywords: Genocide; Aboriginal history; Australian colonisation; settler colonialism

The historical framework used in understanding the ongoing colonisation of Australia directly implicates our knowledge of the present and hopes for the future. The history of Australia, post 1788 invasion, is fraught with contestation, selective forgetting and the appropriation of other people's collective memory (Todorov, 2001). However, history is not fixed and as MacIntyre and Clark (2003) remind us is, "created from the remains of the past and continually being added to and reworked to create newfound knowledge of that past." (MacIntyre and Clark, 2003, p. 29) Consideration of Colin Tatz's identification of an Australian genocide alongside Patrick Wolfe's concept of 'the logic of elimination' within settler colonialism provides such a reworking of knowledge that provides new frameworks in which to analyze Australian colonisation. Through comparison, this essay will explore Tatz's application of genocide in relationship to Wolfe's 'logic of elimination' within settler colonialism.

In his research discussion paper, pertinently titled 'Genocide in Australia', Colin Tatz reframes the colonisation of Australia as an inter-racial history in which he will, "call genocide." (Tatz., 1999, p.2) In doing so, he notes a departure from the epistemology of Australian colonisation at the time of his writing. Historical discussions of settler history had commonly avoided the term 'genocide' in relation to the Aboriginal experience which Tatz questions as either theoretical ignorance or a simple reluctance to, "to taint "the land of the fair go"" (Tatz., 1999, p.2). In fact, as Judith Cameron Bassant suggests, apologist historians have refuted outright any claims of genocidal practices within Australia's colonisation (Bassant, 2013). However, it is important to unpack what Tatz means by an Australian genocide and what implications this has on Australia's colonial history. 
Tatz's dissertation methodically applies the crimes committed/permitted by British arrival and subsequent colonial policy to the ruling of International Law set out in the United Nations Convention on the Prevention and punish of the crime of Genocide (United Nations, 1948). This law treaty, ratified by the Australian government in 1949, sets out the 'universally accepted yardstick' in which Tatz will lay his claims. Of particular note is Article II:

\section{Article II}

.... genocide means any of the following acts committed with intent to destroy, in whole or in part, a national, ethnical, racial or religious group, as such:

a) Killing members of the group;

b) Causing serious bodily or mental harm to members of the group;

c) Deliberately inflicting on the group conditions of life calculated to bring about its physical destruction in whole or in part;

d) Imposing measures intended to prevent births within the group; forcibly transferring children of the group to another group"

(United Nations Convention on the Prevention and punishment of the crime of Genocide, 1948)

Taking this international definition, Tatz asserts Australia to be guilty of, "in a legal sense... at least three, possibly four, acts of genocide." (Tatz. C, 1999, p. 7) Substantive evidence is littered throughout Genocide in Australia as all sections of Article II are indisputably correlated within 'settler-native' relations of Australia's colonial history. For example, in vindicating Australia's complicity in clause a) - "killing members of a group" - Tatz empirically accounts for the slaughter of between 3000 - 4000 Tasmanian Aborigines between 1803 and 1835. This slaughter, he claims, was not merely a retaliation against territorial agitations but rather a murderous outbreak of hatred, “because they were Aborigines." (Tatz, C, 1999, p.12)

However, the most applicable implication of genocide within Australian colonisation arises from the state removal of Indigenous and Torres Strait Islander children from their parents also known as forced assimilation. In April 1997, the Human Rights and Equal Opportunity Commission delivered the Bringing Them Home report. The important work of the commission concluded with confidence, "that between one in three and one in ten Indigenous children were forcibly removed from their families and communities in the period from approximately 1910 until 1970." (The Human Rights and Equal Opportunity Commission, 1997, p. 12) These evidence-based findings, Tatz proposes, stand as statistical evidence of Australia's complicity in committing genocide under clause e) - “... forcibly transferring children of the group to another group." Whether possible remuneration and public acknowledgment can suffice for the despairing experiences and lived trauma of the stolen generations is an entirely separate, but valid, debate. However, if the National Inquiry stands as the starkest and strongest indictment that Australia has knowingly committed genocide (Tatz, 1999) we must evaluate academic thought that may suggest the contrary.

There remain many Australian historians who maintain a position that the removal of Indigenous and Torres Strait Islander children was neither genocidal nor racist but rather an act of state intervention. Aptly marked as apologist thinkers by their contemporaries, the likes of Kevin 
Windschuttle (2002) and Kenneth Maddock (1982), challenge Australia's history as genocidal as, "when half-caste children were taken it was on the grounds of welfare, not race." (Maddock, 2000, p 22). This revisionist approach employs a kind of moralist relativism that supersedes empirical investigation and oral testimony. "Is it possible then," asks Babara Harff, "to have a law that can, through a perverted collective morality, become a murderous weapon?” (Harff, 2003 p. 58)

For Tatz the answer is as a simple: 'yes'. Although a contextual understanding of socio-political influences of time and place are complimentary to any comprehensive historical study, the same emphasis cannot be afforded to notions of morality. If so, a fallacious assumption is taken up that "that ethical ideas are bound to their time and place." (Hillberg, 1996, p. 124) For every such case of false myth, rhetoric and denial, Tatz is able to refute this irreconcilable relativism with oral and written testimony. As for those he deems 'genocide denialists', Tatz can acknowledge that though they may disapprove of Australia's implication within Article II, clause e) of the Genocide convention, "they don’t ever disprove." (Tatz, 1999, p. 27)

Through his alignment of Australian colonial practice and policy towards Australia's Aboriginal people, alongside his discredit of the moral relativism of his detractors, Tatz locates the concept of genocide as wholly applicable to the nation's history. However, does this identification necessarily facilitate a solid conceptual framework for analyzing such history? In his journal article, Settler Colonialism and the colonisation of the Native (2006) the late scholar Patrick Wolfe questions this academic framing as he believes "the genocidal tribunal is the wrong court." (Wolfe, P. 2006, p. 404) Rather, Wolfe places his theory of the logic of elimination at the heart of the Settler Colonialism debate and thus reframes an understanding of genocide as not simply a historical event, but an ongoing structural process.

Wolfe's article makes this point through a comparative study focused on the United States, Australia and Israel-Palestine. To its end, the historical contrast of these geographically disparate however temporally united epochs, the study reveals a significance in framing as, "the hyphenated genocide devalues Indigenous attrition.” (Wolfe, 2006, p. 402) There is an important distinction made between settler-colonial logic of elimination and genocide in his argument. Although settler colonialism has historically manifested as genocidal, Wolfe distinguishes it as, "inherently eliminatory but not invariably genocidal." (Wolfe, 2006, p. 387) The logic of elimination avoids the question of degree but rather mobilizes a broader consideration between spatial movements, biocultural assimilation, willful introduction of disease and mass killing. As Kauanui re-articulates, the logic of elimination is not about the physical destruction of bodies but, "the elimination of native as native." (Kauanui, 2016, p. 43) Here, Wolfe does not relinquish this process as history but more astutely an on-going reality of the Settler Colonial project.

It is important here to deconstruct what Wolfe determines the 'logic of elimination' within discussions of Settler Colonialism. Firstly, settler colonial studies, the academic arena in which Wolfe situates his discussion, was not a field created by Wolfe but by Native Scholars. (Kauanui, 2016) The specific study of Settler Colonialism distinguishes itself from, but does not replace, Indigenous studies or Australian studies. There is a suggestion here that Settler Colonialism is an enduring epistemology as, "when invasion is recognised as a structure rather than an event, its history does not stop." (Wolfe, 2006, p. 402) Wolfe's article uses this argument to suggest the 
usefulness of his theory as, "we can recognize its being in abeyance rather than being a thing of the past - which is to say, we should guard against the recurrence of "genocidal moments". (Wolfe, 2006, p. 403) That is to say, the logic of elimination permeates beyond the past and should be checked and analyzed in present and in future.

The 'genocidal moments' cited by Wolfe as possible outcomes of the settler colonial project, reveal an intersection in thought between himself and Tatz. In the closing arguments of Settler Colonialism and the elimination of the Native, Wolfe challenges the reader:

How, then, when elimination manifests as genocide, are we to retain the specificity of settler colonialism without downplaying its impact by resorting to a qualified genocide?

(Wolfe, 2006, p. 403)

These 'qualified genocides' harken to Tatz's qualitative findings of Australia's legal violation of Article II under the UN's Genocide Convention. Wolfe takes issue with absolving the specificity of settler colonialism within international genocide law as it, "can only disadvantage Indigenous People because it discursively reinforces the figure of lack at the heart of the non-western." His compromise comes in the suggestion of 'structural genocide' to avoid a hierarchy among victims whilst retaining a terminology that holds true to settler colonialism as a structure rather than an event. Structural genocide is thus a more useful framework as it undermines colonialism as a relegation of the past. Here, Settler Colonialism's logic of elimination diffuses mythicized histories that support a perceived end to colonialism within Australia, and the accordant narrative of the end of Indigenous people alongside it. (Kauanui, J. 2016.)

That the project of Settler Colonialism remains an unfinished structural event within Australia today is overwhelmingly evident. In 2017, we received the Uluru Statement from the Heart. Proportionally, Australia's Indigenous and Torres Strait Islander population are the most incarcerated peoples on the planet. Indigenous children remain disproportionately alienated from their parents whilst suicide rates within the community are the highest across the nation. (Australian Bureau of Statistics, 2010.) It is these dimensions of Indigenous crisis that, the Uluru statement concedes, "tell plainly the structural nature of our problem. This is the torment of our powerlessness." (Uluru Statement from the Heart, 2017) Although the processes of settler colonialism in Australia are often challenged they are never eradicated. Unlike qualified genocides, election results have been peripheral in disrupting these structural injustices because, "settler colonialism is relatively impervious to regime change." (Orlff, 2011, p 44) As Wolfe's logic of elimination supports the relevancy of settler colonialism as an ongoing structural event, his theoretical approach provides a framework provides in which we can analyze present inequality.

In conclusion, Australia's colonial history is far from history. As Kehaulani Kauanui states, "though the past-present should be historicized," an understanding of colonialism as a structure exposes the fact it cannot, and should not, be relegated to the past. Colin Tatz's identification of Genocide in Australia does not dispute this, however it only provides a limited scope in which to frame the ongoing persecution of Indigenous peoples. In his conceptualization of genocide in the, 'practical legal sense,' under the UN Genocide Convention, Tatz prosecutes Australia's complicity, at least, in genocidal acts under Article II, Section e). Both oral and written testimony are evidential here along 
with the conclusions of the Bringing Them Home report. As a discursive framework, merely analyzing Australia's history through a genocidal lens values Indigenous persecution as an experience within that history.

Conversely, Wolfe's theory of the logic of elimination extends the analytic discourse to encompass structural process of settler colonialism, "into different modalities, discourses and institutional formations as it undergirds the historical complexification of settler society." (Wolfe, 2006, p. 402) Thus, as a framework for analyzing Australia's colonisation, Wolfe's theory of elimination is more appropriate as it reaches beyond Tatz's notion of historical genocide as an event of the past and sees it rather as on-going structural process.

\section{References}

Bassant, 2013, 'History and Australian Indigenous Welfare Policies', Journal of Policy Studies, Vol 34. Issue 3 pp 310 - 325. https://doi.org/10.1080/01442872.2013.803531

Barta, T. 1984, 'After the Holocaust: consciousness of genocide in Australia', Australia Journal of Politics and History, vol. 31, no. 1, pp. 154 - 61. https://doi.org/10.1111/j.1467$\underline{\text { 8497.1985.tb01330.x }}$

Dobkowski, M \& Walliman, 2000, 'Relations of genocide: land and lives in the colonization of Australia' Genocide and the Modern Age, vol. 2, no. 2, pp. 237 - 51

Gaita, R. 1997, 'Genocide and pedantry', Quadrant, vol XLII, no. 7 \& 8, pp. 41-5

Harff, B. 2003, No Lessons Learned from the Holocaust? Assessing Risks of Genocide and Political Mass Murder Since 1995, American political Science Review, Vol 97, no. 1, pp. 55 - 73. https://doi.org/10.1017/S0003055403000522

Hillberg, R. 1996, The Politics of Memory: The Journey of a Holocaust Historian, Ivan R. Dee, Chicago, p. 152- 200

Human Rights and Equal Opportunity Commission, 2007 Bringing Them Home: National Inquiry into the Seperation of Aboriginal and Torres Strait Islander Children from Their Families, Sydney

Kauanui, J. 2016 "A Structure, Not an Event": Settler Colonialism and Enduring Indigeneity, Emergent Critic Analytic for Alternative Studies, No. 5, Vol 1 pp 40 - 52.

https://doi.org/10.25158/15.1.7

MacIntyre, S \& Clark, A, 2003, What do Historians Do?, The History Wars, Melbourne University Press, Carlton, Victoria, pp $14-31$

Moses, A.D, 2000 'Antipodean genocide? The origins of the genocidal moment in the colonization of Australia', Jounral of Genocide Research, vol. 2, no. 1, pp. 89 - 106.

https://doi.org/10.1080/146235200112427

Referendum Council, 2017, The Uluru Statement from the Heart, accessed at https://antar.org.au/statement-from-the-heart on 22/06/2017 
Tatz, C, 1999, Genocide in Australia, An AITSIS Research Discussion Paper, no. 8. Pp 1 - 55

Todorov, T. 2001, Life in Common, An Essay in General Anthropology, trans. Goslan, K \& Goslan, L. Lincoln and London: University of Nebraska Press, pp. 102- 114

United Nations Convention on the Prevention and punishment of the crime of Genocide, 1948, Treaty Series, vo. 78., p 277, Entry into force, 12 January 1951, In accordance with article XIII

Windschuttle , K. 2009 . The Fabrication of Aboriginal History: The Stolen Generations 18812008 , vol 3, pp. $52-69$.

Wolfe, P, 2006, Settler colonialism and the elimination of the native, Journal of Genocide Research, no. 8 vol. 4, pp 388 - 403. https://doi.org/10.1080/14623520601056240

(C) 2018 by the author. This article is distributed under the terms and conditions of the Creative Commons Attribution license (http://creativecommons.org/licenses/by-nd/4.0/). 